\title{
Gender and Learner Characteristics
}

\author{
Huda Hindal ${ }^{1}$, Norman Reid ${ }^{2 *}$ and Rex Whitehead ${ }^{2}$ \\ ${ }^{1}$ Arabian Gulf University, Bahrain \\ ${ }^{2}$ University of Glasgow, Scotland \\ *E-mail: dr_n@btinternet.com
}

It is well established that girls and boys perform differently in traditional examinations in most countries. This study looks at a sample of 754 school students in Kuwait (aged about 13) and explores how boys and girls differ in the performance in a range of tests related to learner characteristics. The fundamental question is how boys and girls differ in these learner characteristics and do any of the differences relate to examination performance. If the development of such learner characteristic is open to experiences in the formal learning situations, then this opens the door to possible ways to encourage the development of such characteristics, with possible concomitant enhancement of academic performance. The importance of this cannot be underestimated for it gives curriculum planners, textbook writers teachers and examiners potential tools for enhanced learning. In terms of gender, it may well offer some ways forward to ensure that there is equality of opportunity in achieving high academic performance. It is found that girls outperform the boys in tests which measure extent of field dependency, extent of divergency and skills with the visual-spatial (all at $p<0.001$ ). Confirming previous studies, the girls markedly outperform the boys in all school subject examinations but there are no differences in their measured working memory capacities. In looking at the relationships between various combinations of the measurements made, it is found that boys are much more dependent on working memory than girls in performing in examinations, and the boys are also much more dependent on employing skills related to divergent thought in achieving success in examinations. These observations are interpreted in terms of the way boys and girls learn, with girls being more conscientious and willing to memorise than the boys who, in turn, have to rely on working things out for success: girls tend to memorise; boys tend to try to work it out. This may offer an explanation of the greater success of girls in typical examinations where the accurate recall of information is so often the key to success.

Keywords: high ability, gender, learner characteristics, working memory

\section{Introduction}

The whole issue of gender differences in educational performance at various ages has been noted in many studies. For example, Pomerantz et al. (2002) balance up the evidence for better performance by girls in many areas with their increased levels of distress while Mead (2006), in a US context, explores some of the suggested explanations. Thus, the differences have been related to different developmental stages, possible biases in the way material is presented, the differences in learning preferences between boys and girls as well as the value or otherwise of co-educational provision. While it is possible to modify teaching materials to make them more gender-neutral, there are gender differences in development that cannot be altered and the choice of co-educational provision or gender separation is often determined for religious or cultural reasons. The most interesting area that is received little attention relates to learner characteristics.

The powerful effect of learner characteristics in relation to academic performance has been considered by Hindal et al. (2013). The way such characteristics differ across a population may be attributed to: 


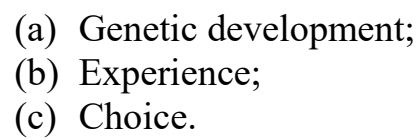

Thus, Mead (2006) refers to differences in learning preferences between boys and girls, this assuming an element of choice. However, genetic factors may be pre-determined and not open to change. The real area of interest lies in experience and this can include formal experience in education or the numerous informal learning experiences that are part of life and growing up. The fundamental question is how boys and girls differ in these learner characteristics and do any of the differences relate to examination performance. If the development of such learner characteristic is open to experiences in the formal learning situations, then this opens the door to possible ways to encourage the development of such characteristics, with possible concomitant enhancement of academic performance. The importance of this cannot be underestimated for it gives curriculum planners, textbook writers teachers and examiners potential tools for enhanced learning. In terms of gender, it may well offer some ways forward to ensure that there is equality of opportunity to achieving high academic performance.

This study looks at a range of learner characteristics and relates these to performance in the entire curriculum. The study looked at three consecutive groups of grade 7 Kuwaiti school students (aged about 13). At this stage, the curriculum in Kuwait is built around six subject areas: Arabic, English, Mathematics, Science, Social Studies and Islamic Studies. Boys and girls are educated in separate schools in Kuwait. The samples of students studied are described in Table 1.

Table 1. The Data Description

\begin{tabular}{ccccl}
\hline Stages & Schools & Girls & Boys & \multicolumn{1}{c}{ Description } \\
\hline Group 1 & 13 & 311 & 330 & High proportion of 'able' students \\
Group 2 & 10 & 71 & 113 & Randomly selected \\
Group 3 & 14 & 320 & 434 & Randomly selected \\
\hline
\end{tabular}

The study was part of a study focussing on students regarded as ' gifted' in the Kuwaiti education system. These 'gifted' students are selected primarily on the basis of high performance on all six subject areas in the curriculum and are offered enrichment experiences in their learning (Hindal et al., 2009). Thus, group 1 is very different in nature when compared to the other two groups. The sample involved nearly 50\% who were classified as very able under the Kuwaiti system (Hindal et al., 2013). Access to the student groups did not allow every measurement to be made with every student. However, all the three samples were drawn from a wide range of schools, reflecting the typical make-up of the Kuwaiti population at this age.

\section{The Study Aims}

The aim was to explore differences in performance of boys and girls in the various tests used and to see whether the relationships between these test data differ. The data from each of the grade 7 samples are considered in turn and then conclusions are drawn by looking at the findings from all three groups.

The following measurements were made (Table 2), details of the tests being described in Hindal et al. 2009). 
Table 2. Measurements Made

\begin{tabular}{|c|c|c|c|c|}
\hline & Sample & Measurement & Test Used & Source \\
\hline \multirow{5}{*}{$\begin{array}{c}\text { Group } \\
1\end{array}$} & \multirow{5}{*}{$\begin{array}{l}641 \\
\text { High proportion of } \\
\text { 'gifted' students } \\
\text { girls }=311 \\
\text { boys }=330\end{array}$} & Working memory capacity & Figural intersection test & $\begin{array}{l}\text { Pascual-Leone } \\
\text { (1970) }\end{array}$ \\
\hline & & $\begin{array}{l}\text { Extent of Field } \\
\text { Dependency }\end{array}$ & $\begin{array}{l}\text { Group Embedded Figures } \\
\text { Test }\end{array}$ & $\begin{array}{l}\text { Witkin et al. } \\
\text { (1971) }\end{array}$ \\
\hline & & Extent of Divergency & Shapes Test & $\begin{array}{l}\text { Hudson (1962, } \\
1968)\end{array}$ \\
\hline & & Visual-spatial skills & $\begin{array}{l}\text { A new visual-spatial skills } \\
\text { test }\end{array}$ & $\begin{array}{l}\text { Hindal et al. } \\
\text { (2009) }\end{array}$ \\
\hline & & Examination marks & $\begin{array}{l}\text { School National Examina- } \\
\text { tions }\end{array}$ & $\begin{array}{l}6 \text { subjects, marks } \\
\text { standardised }\end{array}$ \\
\hline \multirow{2}{*}{$\begin{array}{l}\text { Group } \\
2\end{array}$} & \multirow{2}{*}{$\begin{array}{l}184 \\
\text { Randomly selected } \\
\text { girls }=71 \\
\text { boys }=113\end{array}$} & Visual-spatial skills & Computer-driven test & $\begin{array}{l}\text { Hindal et al., } \\
\text { (2009) }\end{array}$ \\
\hline & & Examination marks & $\begin{array}{l}\text { School National Examina- } \\
\text { tions }\end{array}$ & $\begin{array}{l}6 \text { subjects, marks } \\
\text { standardised }\end{array}$ \\
\hline \multirow{4}{*}{$\begin{array}{l}\text { Group } \\
3\end{array}$} & \multirow{4}{*}{$\begin{array}{l}754 \\
\text { randomly selected } \\
\text { girls }=320 \\
\text { boys }=434\end{array}$} & Extent of Divergency & Shapes Test & Hudson (1962) \\
\hline & & Extent of Convergency & New test & $\begin{array}{l}\text { Hindal et al. } \\
(2009)\end{array}$ \\
\hline & & Examination marks & $\begin{array}{l}\text { School National Examina- } \\
\text { tions }\end{array}$ & $\begin{array}{l}6 \text { subjects, marks } \\
\text { standardised }\end{array}$ \\
\hline & & Visual-spatial skills & Computer-driven test & $\begin{array}{l}\text { Hindal et al. } \\
\text { (2009) }\end{array}$ \\
\hline
\end{tabular}

Previous studies have shown that all these learner characteristics are related to performance in typical school and university examinations. Each is now outlined briefly.

\section{Working Memory Capacity}

Working Memory has been studied extensively by Baddeley $(1986,2002)$ and details of the way this part of the brain works are now well documented. Working Memory Capacity is known to correlate (often highly) with academic performance as measured in typical examinations and tests, especially in highly conceptual areas of the curriculum (the sciences and mathematics). It is here that the handling of information and thinking processes make working memory capacity important for academic success (Johnstone, 1997; Johnstone et al., 1998; Johnstone, 2000; Danili \& Reid, 2004, Al-Ahmadi \& Oraif, 2009; Reid, 2009a,b; Ali \& Reid, 2011). These studies show much higher correlation values where the tests involved required thinking and processing skills in solving problems. Correlation values up to 0.69 have been observed while the work of Johnstone and El-Banna $(1986,1989)$ has shown that the relationship is cause and effect. Kirschner et al. (2006: 77) have signalled the key importance of limited working memory capacity when they note that, 'Any instructional theory that ignores the limits of 
working memory when dealing with novel information or ignores the disappearance of these limits when dealing with familiar information in unlikely to be effective'.

The test to measure working memory capacity was developed originally by Pascual-Leone (1970). This is a highly visual test but it gives results which agree well with other measures of working memory (Johnstone \& El-Banna, 1986, 1989). The test is easy to administer. The test involves holding and manipulating various geometrical shapes in the working memory and students are asked to find, within a fixed time, the common area enclosed by a number of overlapping shapes. These are presented both overlapped and separately. Success with up to $\mathrm{N}$ shapes indicates a working memory capacity of N (Chen \& Whitehead, 2009).

\section{Extent of Field Dependency}

This construct was developed in the work of Witkin (Witkin, 1949; Witkin et al., 1967, 1974, 1977; Witkin and Goodenough, 1981) and many studies have shown that those who are field independent always perform better in examinations and tests when compared to those who are field dependent (Tinajero \& Paramo, 1997). The field independent person can separate the key information from its context or field. Johnstone described this usefully as the ability to select the 'message' from the 'noise', an idea first proposed by Johnstone and Wham (1982).

A Group Embedded Figures Test has been used in many studies (Johnstone and El-Banna, 1986; Al-Naeme \& Johnstone, 1991; Bahar \& Hansell, 2000; Danili \& Reid, 2004; Tsaparlis, 2005). The test is a timed, written test, making its use straightforward. The test booklet comprises 20 complex figures. The student has to find a simple shape which is embedded in a complex matrix of shapes. The simple shape is given to the student and they are asked to trace the shape hidden in the matrix, the shape being of the same size, the same proportions, facing in the same direction, with only one shape within each pattern.

\section{Extent of Divergency}

Hudson $(1962,1966,1968)$ developed the idea of convergency and divergency, finding advantages in different situations for those who were strongly convergent and those who were strongly divergent. There is huge literature on the characteristics and the descriptions have been summarised by Bahar (1999), bringing together the work of many others (Table 3). The test used here was identical (apart from minor adjustments due to the use of Arabic) to the test used by previous researchers (Bahar et al, 1999, Danili \& Reid, 2005). There were six timed sub-tests, with a total time limit of 20 minutes.

\section{Extent of Convergency}

The test for divergency essentially measures extent of divergency and it was usually assumed that a low score indicated high convergency. It has now been shown that convergency is a learner characteristic in its own right, and needs its own test. Indeed, Hudson (1968:91) never saw the capacity as fixed and noted that,

'No one was, or was ever expected to be consistently convergent or consistently divergent. I have never seen why someone should not drift slowly over a period of years from divergence to convergence, or vice versa. Nor why someone should not be divergent in some moods and convergent in others. Nor why someone might not be convergent (or divergent).' 
Table 3. Characteristics of Being Convergent and Divergent

\begin{tabular}{ll}
\hline Converger Characteristics & Divergers Characteristics \\
\hline Higher performance in intelligence tests & Higher performance in open-ended tests \\
Good at the practical application of ideas & Good at generating ideas \\
Specialised in physical science and classics & Good at seeing things from different perspec- \\
Prefer formal materials and logical arguments & tives \\
Ability to focus hypothetical-deductive & Specialised in the arts \\
reasoning on specific problems & Better in concrete experience \\
Better in abstract conceptualisation & Interested in people \\
Hold conventional attitudes & Hold unconventional attitudes \\
Like unambiguity & Strong in imaginative ability \\
Emotionally inhibited & More likely to be witty \\
\hline
\end{tabular}

The first attempt to develop a test (in Arabic) specifically to measure convergency has been described in Hindal et al. (2009), summarising the work of Hindal (2007). Subsequent to that study, the test was used (in English) with 45 Scottish school students (aged 13 years) and the responses discussed with small groups of students after they had completed the test, using several experienced interviewers. The way the students responded to the test items corresponded well with the intentions of the test writer, suggesting that test validity was robust. This test, in Arabic but unaltered, was used here.

\section{Visual-Spatial Skills}

Although visual-spatial ability is often discussed, no specific test was found to measure it (Silverman, 1989, 2002, 2003). However, Hindal et al. (2009) describe a computer-driven test to measure visualspatial skills. Looking at the literature (eg. Johnson, 1996; Silverman, 1989, 2002, 2003; Golon, 2004), the following skills were identified as part of the visual-spatial learner characteristic.

Table 4. Skills related to Visual-spatial Ability

\begin{tabular}{l}
\hline \multicolumn{1}{c}{ Skill to be Measured } \\
\hline Discrimination between different forms and shapes \\
Focus in the counting of shapes, in different sizes and position \\
Distinguish between figures and their backgrounds and inverse images \\
Estimation of distances and velocities \\
Accurate perception of shapes and number of shapes \\
Speed tracking information visually \\
\hline
\end{tabular}

The test was designed to reflect ability in these skills. The test was computer-driven allowing for movement, colour and simple forms of animation and projected onto a screen. Hindal et al. (2009) describe the development of the test and the processes through which it went in an attempt to gain some evidence of validity. 


\section{Group 1}

In the first experiment, working memory capacity and the three learner characteristics were measured. The marks in six subjects were standardised and combined to give a total mark. The performance of girls and boys are now compared and table 5 shows the basic statistics for the sample. All the data show close approximations to normal distributions.

Table 5. Performance Data by Gender $(\mathrm{N}($ girls $)=311, \mathrm{~N}($ boys $=330)$

\begin{tabular}{lcccccc}
\hline & Gender & Sample & Mean & $\begin{array}{c}\text { Standard } \\
\text { Deviation }\end{array}$ & $\begin{array}{c}\text { t-test } \\
\text { Value }\end{array}$ & Probability \\
\hline Total Marks (standard- & girls & 311 & 62.0 & 8.2 & 5.7 & $\mathrm{p}<0.001$ \\
ised) & boys & 330 & 58.1 & 9.1 & & \\
Working Memory Capac- & girls & 311 & 4.1 & 1.6 & & n.s. \\
ity & boys & 330 & 4.3 & 1.6 & & \\
Extent of Field Depend- & girls & 289 & 2.3 & 1.8 & & \\
ency & boys & 316 & 1.8 & 1.4 & 3.9 & $\mathrm{p}<0.001$ \\
Extent of Divergency & girls & 274 & 38.0 & 10.2 & & \\
& boys & 318 & 29.8 & 11.0 & 9.3 & $\mathrm{p}<0.001$ \\
Visual-Spatial test & girls & 281 & 18.2 & 4.9 & & \\
& boys & 279 & 16.3 & 5.3 & 4.3 & $\mathrm{p}<0.001$ \\
\hline
\end{tabular}

Girls are superior to boys in all the measurements except those for the working memory capacity where it is well established that there are no differences related to gender (Hindal, 2007). Indeed, the differences in the other characteristics are marked and, in the case of divergency, very marked indeed. At this age, girls tend to outperform boys in examinations. Frey (1991) noted this long ago but even very recent national examination statistics reveal that females accounted for about $55 \%$ of the entries at Scottish Higher Grade (national examination, sat at age 17-18), with slightly better pass rates than boys (SQA, 2010). However, girls are also markedly superior to boys in the other three characteristics although it has to be recognised that the sample is not random. Thus, at this age with this sample, girls are more field independent, more divergent and have better visual-spatial abilities as measured by the visual-spatial test.

There is wide recognition that males excel over females across a variety of visual-spatial problemsolving and perceptual tasks (Broverman et al., 1968; Harris, 1978; Joseph, 2000; Kimura, 1993; Linn and Petersen, 1985; Thomas et al., 1973). It is possible that a developmental factor may be operating: girls are more developed during their teenage years. However, it is more likely that the fact that girls and boys are educated separately causes the differences. Observations in the schools shows the greater use of visual materials in girls schools in Kuwait.

Working memory capacity and the three learner characteristics have all been shown to correlate with examination performance (Hindal et al., 2009) and, therefore, relate to 'giftedness' as defined in Kuwait. In that girls outperform boys in the three learner characteristics, they will tend to be selected as gifted more than boys. The real question is whether the relationship between these characteristics and performance is equal for both boys and girls. Table 6 shows the Pearson correlations found by looking at the genders separately.

(C) 2013, European Journal of Educational Research, 2(2), 83-96 
Table 6. Correlation Data by Gender

\begin{tabular}{|c|c|c|c|c|c|}
\hline \multirow{9}{*}{$\begin{array}{c}\text { Girls } \\
\mathrm{N}=311\end{array}$} & & Field Dependency & Divergency & Visual-Spatial & Total marks \\
\hline & & 0.29 & 0.23 & 0.19 & 0.15 \\
\hline & $\begin{array}{c}\text { ory } \\
\text { Capacity }\end{array}$ & $\mathrm{p}<0.001$ & $\mathrm{p}<0.001$ & $\mathrm{p}<0.001$ & $\mathrm{p}<0.01$ \\
\hline & Extent of Field & & 0.21 & 0.34 & 0.16 \\
\hline & Dependency & & $\mathrm{p}<0.001$ & $\mathrm{p}<0.001$ & $\mathrm{p}<0.01$ \\
\hline & Extent of Diver- & & & 0.37 & 0.41 \\
\hline & gency & & & $\mathrm{p}<0.001$ & $\mathrm{p}<0.001$ \\
\hline & Visual-Spatial & & & & 0.30 \\
\hline & Test & & & & $\mathrm{p}<0.001$ \\
\hline \multirow{8}{*}{$\begin{array}{c}\text { Boys } \\
N=330\end{array}$} & Working Mem- & 0.34 & 0.28 & 0.26 & 0.31 \\
\hline & $\begin{array}{c}\text { ory } \\
\text { Capacity }\end{array}$ & $\mathrm{p}<0.001$ & $\mathrm{p}<0.001$ & $\mathrm{p}<0.001$ & $\mathrm{p}<0.001$ \\
\hline & Extent of Field & & 0.26 & 0.21 & 0.14 \\
\hline & Dependency & & $\mathrm{p}<0.001$ & $\mathrm{p}<0.001$ & $\mathrm{p}=0.05$ \\
\hline & Extent of Diver- & & & 0.35 & 0.62 \\
\hline & gency & & & $\mathrm{p}<0.001$ & $\mathrm{p}<0.001$ \\
\hline & Visual-Spatial & & & & 0.30 \\
\hline & Test & & & & $\mathrm{p}<0.001$ \\
\hline
\end{tabular}

With samples of this size, a correlation around 0.1 is significant at $p<0.05$. On this basis, correlations for girls and boys which differed by at least 0.1 are now considered (Table 7 ).

Table 7. Gender Differences in Correlations $(\mathrm{N}($ girls $)=311, \mathrm{~N}($ boys $)=330)$

\begin{tabular}{ccccc}
\hline \multicolumn{2}{c}{ Correlates } & \multicolumn{3}{c}{ Pearson Correlations } \\
& & Girls & Boys & Difference \\
\hline Working Memory Capacity & Total marks & 0.15 & 0.31 & 0.16 \\
Extent of Divergency & Total marks & 0.41 & 0.62 & 0.22 \\
Extent of Field Dependency & Visual-Spatial Test & 0.34 & 0.21 & 0.13 \\
\hline
\end{tabular}

The role of working memory is important in seeking an interpretation of the findings. The working memory is used to hold and manipulate information (Johnstone, 1997). Understanding relies critically on the working memory to make sense of incoming information so that it can be related to previ- 
ous knowledge. It is possible that girls are relying more on straightforward memorisation as they tend to be much more conscientious at this age (Steinberg, 2005) while the boys are having to work things out to reach answers. The working memory is critical for the 'working out' process.

In simple terms, faced with an examination question, the girls may tend to search their long-term memory for memorised relevant information and this is then transferred to the examination script. For the boys, their search of long-term memory may be less successful in that they have memorised less. The working memory is then more heavily involved seeking related information and then seeking to interpret it in order to reach an answers for the examination question. Thus, it is possible to suggest that the working memory is employed more with boys than girls at this age, offering a possible explanation of the higher correlation with examination success.

There is also a marked difference in the correlation values for divergency and total marks, the boys showing a much higher correlation value for the relationship. Again, if boys are having to work things out more, then they will be searching through their long-term memory for possible ideas and answers and being divergent might offer many more links in long term memory (see Reid and Yang, 2002; Al-Qasmi, 2006) making being divergent a more powerful influence on likely success.

With field dependency and visual-spatial abilities, the correlation is higher for girls. This is more difficult to explain although, in the separate gender schools in Kuwait, there is a much more marked emphasis on the visual in the girls (use of visual aids) schools than in the boys and this might be the basis for the reason.

One overall effect, in terms of selection for giftedness is that, if performance in examinations in Kuwait is highly dependent on recall skills (Hindal at al, 2009), then it places boys in a different position relative to girls in that characteristics like divergency are more important. Thus, boys who happen not to be divergent have extra disadvantages.

However, the sample used in this experiment was not random. Two further experiments were conducted using totally random samples but access to students made it difficult to run all the test with either group. Firstly, experiment 2 was conducted with a small sample to explore the visual-spatial outcomes further.

\section{Group 2}

A fresh random sample of 184 Kuwaiti school students (aged 13) undertook the visual-spatial test and the performance for girls and boys in this test are compared. This experiment focussed on the visual spatial, exploring if the correlation with performance would be repeated with a random sample or was peculiar to those who were more highly able. The basic statistics for the sample are shown in table 8 .

Table 8 . Visual-spatial Test by Gender $(\mathrm{N}(\operatorname{girls}=71, \mathrm{~N}($ boys $)=113)$

\begin{tabular}{lcccccc}
\hline & Gender & Sample & Mean & $\begin{array}{c}\text { Standard } \\
\text { Devia- } \\
\text { tion }\end{array}$ & t-test Value Probability \\
\hline Visual-Spatial & Girls & 71 & 17.5 & 6.6 & 2.6 & $p<0.05$ \\
test & Boys & 113 & 15.2 & 5.6 & & \\
\hline
\end{tabular}


Table 8 shows that there is low significant difference between the boys and the girls in the performance in the visual-spatial test, again with the girls outperforming the boys. This is consistent with experiment 1 although the t-test value is lower but the sample for group 2 is not selected in any way. The outcomes suggest that the visual-spatial may be more important for the more able, with more marked gender differences. This is consistent with the observation that the more able often show enhanced visual-spatial skills [for example, Einstein (Aldous, 2007)]. However, in Kuwait's gender separated schools, the girls are exposed to more visual-spatial and this may offer a more obvious explanation.

Table 9. Correlations by Gender

\begin{tabular}{ccc}
\hline Gender & Visual-Spatial Test \\
\hline Girls & Total Marks & 0.35 \\
$\mathrm{~N}=71$ & $\mathrm{p}<0.01$ \\
\hline Boys & Total Marks & 0.28 \\
$\mathrm{~N}=113$ & & $\mathrm{p}<0.01$ \\
\hline
\end{tabular}

Table 9 shows that boys and girls tend to be similar in the way their visual-spatial ability (as measured by the test) relate to performance in examinations, similar to experiment 1 data. Thus, in Kuwait, at age 13, both boys and girls who are visual-spatially more equipped will tend to perform better in examinations. The effect is similar for a random sample when compared to a sample containing a high proportion of 'gifted 'students.

\section{Group 3}

It now proved possible to gain access to a wider random sample $(\mathrm{N}=754)$ to explore learner characteristics further. However, it was not possible for every student to complete every test, the descriptive statistics being shown in table 10. In this experiment, the new test for convergency was used.

Table 10. Test Data by Gender

\begin{tabular}{lcccccc}
\hline & Gender & $\mathrm{N}$ & Mean & $\begin{array}{c}\text { Standard } \\
\text { Deviation }\end{array}$ & t-test Value & Probability \\
\hline \multirow{2}{*}{ Total Marks } & Girls & 320 & 62.9 & 10.0 & 7.0 & $\mathrm{p}<0.001$ \\
& Boys & 434 & 57.9 & 9.4 & & \\
Extent of Conver- & Girls & 292 & 11.0 & 3.5 & 4.6 & $\mathrm{p}<0.001$ \\
gency & Boys & 366 & 9.7 & 3.7 & & \\
Visual-spatial Test & Girls & 138 & 11.3 & 3.1 & 2.2 & $\mathrm{p}<0.05$ \\
& Boys & 174 & 10.5 & 3.5 & & \\
Extent of Divergency & Girls & 162 & 31.6 & 10.7 & 5.3 & $\mathrm{p}<0.001$ \\
& Boys & 261 & 26.2 & 9.7 & & \\
\hline
\end{tabular}


With this random sample, the girls outperform the boys in all tests, consistent with the pattern derived from group 1. The outcomes from the various tests were now inter-correlated, looking at boys and girls separately (Table 11).

Table 11. Correlations by Gender

\begin{tabular}{ccccc}
\hline & & $\begin{array}{c}\text { Extent of Conver- } \\
\text { gency }\end{array}$ & Visual-spatial Test & Extent of Divergency \\
\cline { 2 - 5 } Girls & Total Marks & 0.49 & 0.32 & 0.36 \\
$\mathrm{~N}=292$ & $\mathrm{p}<0.001$ & $\mathrm{p}<0.001$ & $\mathrm{p}<0.001$ \\
& $\begin{array}{c}\text { Extent of Conver- } \\
\text { gency }\end{array}$ & & 0.39 & 0.52 \\
& Total Marks & 0.49 & $\mathrm{p}<0.001$ & $\mathrm{p}<0.001$ \\
\hline \multirow{2}{*}{ Boys } & $\mathrm{p}<0.001$ & 0.28 & 0.37 \\
$\mathrm{~N}=366$ & Extent of Conver- & & $\mathrm{p}<0.001$ & $\mathrm{p}<0.001$ \\
& gency & & 0.39 & 0.52 \\
& & & $\mathrm{p}<0.001$ & $\mathrm{p}<0.001$ \\
\hline
\end{tabular}

The data in table 11 show that the correlations of the various tests with total marks are almost identical, this sample being a random cross-section of the population. This is not the same as the pattern obtained from experiment 1 where the sample containing a very high proportion of those deemed ' gifted'. There is one key difference when comparing the outcomes here with those from group 1 . The correlation of extent of divergency with examination performance for boys in group 1 was much higher than for girls. However, in group 3 - with the totally random sample - the correlation values are more or less identical.

For all school students at this age, extent of divergency is a powerful correlate of examination performance. However, for highly able boys, the correlation is most marked. It is relatively straighforward to suggest a possible interpretation of why divergency is a powerful correlate of examination success. Thus, being divergent means being able to use (or generate) links between ideas. It has been established that divergency correlates with performance (Danili \& Reid, 2005) and, particularly, problem solving ability (Al-Qasmi, 2006). In the latter study, it was suggested that this was dependent on the presence of usable, accessible links between ideas in long term memory (Hindal et al., 2009).

However, the finding for highly able boys is fascinating. The results suggest that, for high performing boys, they either choose or are more equipped to work things out and rely less on memorisation. Therefore, the ability to use links in long-term memory is very important and the more divergent have a very considerable advantage in that they have more links available for use. Divergent skills are related to creativity. Thus, being able to use (or generate) links between ideas offers the possibility of generating ideas. This skill is in great demand in society and its encouragement in schools is to be applauded. Sadly, school curricula and national examinations tend to force learners to conform and the desirable skills may well be suppressed (Robinson, 2011). 


\section{Discussion}

The aim of this study is investigate the differences between the girls and boys in several learner characteristics (field dependency, divergency, convergency and visual-spatial) as well as working memory capacity. The observed differences are related to examination performance in grade 7 in Kuwait (age about 13). The results show there are very significant differences between the girls and boys in all these characteristics except for working memory capacity. Working memory capacity is known to be gender neutral. One fundamental question is why these observed differences occur. It is perfectly possible that the superiority of the girls is due to more mature development, given that the students are in the middle of adolescence when development moves so rapidly. It is also possible that, in gender separated schools, these characteristics have been given a greater opportunity to develop (assuming that development is possible) differentially.

It has to be noted that the gender differences in learner characteristics can be conceptualised in terms of genetics, experience or choice, these possibilities not being mutually exclusive. Thus, girls develop much more rapidly than boys during adolescence and this can account for observed differences. In a system of gender-separated education, it may simply be that the experiences in formal schooling for boys and girls are sufficiently different to generate gender differences in learner characteristics. Indeed, girls and boys may choose different ways of learning, for a variety of reasons reflecting different experiences or cultural norms.

Measurements of the learner characteristics considered here show considerable gender differences. If such differences are influencing examination performance, then it means that girls have a very significant advantage in being selected as 'gifted' on the basis of examination marks (the practice in Kuwait). Indeed, it may mean that girls have advantages in selection for many other opportunities (eg. careers, entry to Higher Education). This may simply be a function of the way examinations are set and marked. The rewards in terms of examination performance are reflecting the way girls work more than the way boys work.

With samples drawn from the whole population (experiments 2 and 3), the relationships between the learner characteristics and performance are similar for boys and girls. However, with the sample which contained a high proportion of those considered to be 'gifted' (group 1), the benefits of having a high working memory capacity and being divergent are very much more powerful for boys than for girls in relation to their examination performance. This might be explained in terms of the boys being less willing to work hard at memorisation and, therefore, being more dependent on having to work things out, the highly able boys being capable of doing this.

This has important implications. It might suggest that high ability with girls relates to a greater ability (and/or willingness) to memorise and recall accurately. By contrast, high ability with boys may well depend on enhanced skills in being able to work things out. This is consistent with findings obtained by Al-Ahmadi (2008) where she noted marked gender differences related to the way working memory was used. In essence, working memory capacity is more important as a determinant of academic success for boys in that, naturally, they want to work things out rather than memorise them.

However, this effect does not show with the whole population and this suggests that the high achiever boys are those who are either choose or are more equipped to work things out and rely less on memorisation. This needs much more exploration and may be very important when looking at 'giftedness'. Indeed, the whole area of divergent thought and the related idea of creativity needs rethought within schools.

Divergent thought can be conceptualised as the ability and/or willingness to generate links between ideas in long-term memory. It is not known if this ability is simply genetic or can be enhanced. What is known is that the capacity to link ideas is a very complex process and is not easy (Reid \& Yang, 2002), this being confirmed by the work of Al-Qasmi (2006). The whole area of creativity has 
been considered by Robinson (2011). He argues for the vital importance of this skill in all education and gives ample evidence of the way formal education tends to suppress the skill.

If divergency, as a learner characteristic, is so important in relation to academic performance, then there is a pressing need to encourage the skill of being divergent. If creativity is so important in any school or university population (and it is difficult to argue against the Robinson thesis), then the importance of encouraging divergent thought becomes even more pressing in that divergency may well be a key in developing creative thought (Robinson, 2011).

\section{Conclusions}

This study has shown that, overall, girls out-perform boys at age 13 in Kuwait in tests of visual-spatial ability, extent of divergency and extent of divergency and that their performance in these test correlates highly with examination performance where girls also out-perform boys. With more able boys and girls, the differences in these tests (as well as in extent of field dependency) is more marked and the relationships with academic performance are more markedly different by gender. In every case, girls outperform boys while, with the most able group, the correlations of working memory capacity, extent of divergency and extent of field dependency are much more strongly correlated with academic success for boys. With boys tending to rely more on working things out compared to the girls who are more reliant on accurate recall of memorised information, this may offer an explanation of the greater success for girls in typical examinations where the accurate recall of information is so often the key to success.

\section{References}

Al-Ahmadi, F.M. (2008) The development of scientific thinking with senior school physics students, PhD Thesis, University of Glasgow, Glasgow. (http://theses.gla.ac.uk/241/)

Al-Ahmadi, F., \& Oraif, F. (2009). Working memory capacity, confidence and scientific thinking, Research in Science and Technological Education, 27(2), 225-243.

Aldous, Carol, (2007). Creativity, problem solving and innovative science: insights from history, cognitive psychology and neuroscience, International Education Journal, 8(2), 176-186.

Ali, A.A., \& Reid, N. (2011). Understanding mathematics: Some key factors, European Journal of Educational Research, 1(3), 283-299.

Al-Qasmi, S. (2006). Problem solving in biology at university level, PhD Thesis, Glasgow: University of Glasgow.

Al-Naeme, F., \& Johnstone, A.H. (1991). Room for Scientific Thought?, International Journal of Science Education, 13 (2), 187-192.

Baddeley, A. (1986). Working memory. Oxford: Clarendon Press.

Baddeley, A.D. (2002). Is working memory still working, European Psychologist, 7(2), 85-97.

Bahar, M. (1999). Investigation of biology students' cognitive structure through word association tests, mind maps and structural communication grids, PhD Thesis, University of Glasgow, Glasgow.

Bahar, M., \& Hansell, M.H. (2000). The relationship between some psychological factors and their effect on the performance of grid questions and word association tests, Educational Psychology, 20(3), 349-364.

Bahar, M. Johnstone, A.H., \& Sutcliffe, R.G. (1999). Investigation of students cognitive structure in elementary genetics through word association tests, Journal of Biological Education, 33(3), 134142.

Broverman, D. Vogel, W. Klaiber, E. Majcher, D. Shead, D., \& Paul, V. (1968). Roles of activation and inhibition in sex differences in cognitive abilities. Psychological Review, 48, 328-331. 
Chen, W-C., \& Whithead, R. (2009). The understanding of physics in relation to working memory, Research in Science and Technological Education, 27(2), 151-160.

Danili, E. \& Reid, N. (2004). Some strategies to improve performance in school chemistry, based on two cognitive factors. Research in Science and Technological Education, 22(2), 203-226.

Danili, E. \& Reid, N. (2005). Assessment formats: do they make a difference? Chemistry Education Research and Practice, 6(4), 198-206.

Frey, D. (1991). Psychosocial needs of the gifted adolescent. In: Bireley, M. and Genshaft, J. (Eds) Understanding the Gifted Adolescent: Educational, Developmental, and Multicultural Issues. New York: Teacher College, Columbia University.

Golon, A. (2004). Raising Topsy-turvy kids: Successfully Parenting Your Visual-Spatial Child, Denver: Deleon Publishing.

Harris, L. (1978). Sex Differences in Spatial Ability. In: Kinsbourne, M. (Ed.), Asymmetrical Function of the Brain. New York: Cambridge University Press.

Hindal, H.S. (2007). Cognitive characteristics of students in middle schools in State of Kuwait, with emphasis on high achievement, $\mathrm{PhD}$ Thesis, University of Glasgow, Glasgow.

Hindall, H., Reid, N., \& Badgaish, M. (2009). Working Memory, Performance and Learner Characteristics, Research in Science and Technological Education, 27(2), 187-204.

Hindal, H., Reid, N., \& Whitehead, R. (2013). A fresh look at high ability. International Journal of Instruction. 6(1), 59-76.

Hudson, L (1962). Intelligence, Divergence and Potential originality, Nature, 601-2.

Hudson, L. (1966). Contrary Imaginations: A Psychological Study of the English Schoolboy, London: Penguin Books.

Hudson, L. (1968). Frames of Mind: Ability, Perception and Self-Perception in the Arts and Science, New York: Norton.

Johnson, N. (1996). Look Closer: Visual Thinking Skills and Activities, Ohio: Pieces of Learning

Johnstone, A.H. (1997). Chemistry Teaching-Science or Alchemy?. Journal of Chemical Education, 74(3), 262-268.

Johnstone, A.H. (2000). Teaching of Chemistry - Logical or Psychological? Chemistry Education Research and Practice, 1(1), 9-15.

Johnstone, A.H., El-Banna, H. (1986). Capacities, demands and processes: a predictive model for science education. Education in Chemistry, 23(3), 80-84.

Johnstone, A.H. \& El-Banna, H. (1989). Understanding Learning Difficulties - A Predictive Research Model, Studies in Higher Education, 14(2), 159-68.

Johnstone, A.H. \& Wham, A.J.B. (1982). Demands of practical work, Education in Chemistry, 19(3), 71-73.

Johnstone, A.H. Watt, A., \& Zaman, T. (1998).The students' attitude and cognition change to a physics laboratory. Physics Education, 33(1), 22-29.

Joseph, R. (2000). The Evolution of Sex Differences in Language, Sexuality, and Visual-Spatial Skills. Archives of Sexual Behavior, 29(1), 35.

Kimura, D. (1993). Neuromotor mechanisms in human communication. New York: Oxford University Press.

Kirschner, P.A., Sweller, J. \& Clark, R.E. (2006). Why minimal guidance during instruction does not work: an analysis of the failure of constructivist, discovery, problem-based, experiential, and inquiry-based learning. Educational Psychologist, 41(2), 75-86.

Linn, M. \& Petersen, A. (1985). Emergence and characterization of sex differences in spatial ability: A meta-analysis. Child Development, 56, 1479-1498.

Mead, S. (2006). The Evidence Suggest Otherwise, The Truth about Boys and Girls, www.educationsector.org 
Pascual-Leone, J. (1970). A mathematical model for the transition rule in Piaget's developmental stages, Acta Psychologica. 32, 301-345.

Pomerantz, E. M., Altermatt, E. R., Saxon, J. L. (2002). Making the grade but feeling distressed: Gender differences in academic performance and internal distress. Journal of Educational Psychology, 94(2), 396-404.

Reid, N. (2009a). The concept of working memory. Research in Science and Technological Education, 27(2), 131-138.

Reid, N. (2009b). Working Memory and Science Education, Research in Science and Technological Education, 27(2), 245-250.

Reid, N., \& Yang, M-J. (2002). The Solving of Problems in Chemistry: The More Open-ended Problems, Research in Science and Technological Education, 20(1), 83-98.

Robinson, K., (2011). Out of Our Minds: learning to be Creative, Capstone Publishing Ltd, Chichester.

Silverman, L. (1989). The Visual-Spatial Learner, Preventing School Failure, 34, 15-20.

Silverman, L. (2002). Upside-down brilliance: The Visual-Spatial Learner, Under the Title, "Making Quick Work of Math Facts," 302-305. Denver: DeLeon.

Silverman, L. (2003). The visual-spatial learner: An introduction. Soundview School Dolphin News. 67.

SQA (2010) Statistics (2010), Scottish Qualifications Authority, accessed at: http://www.sqa.org.uk/sqa/42887.html

Steinberg, L. (2005). Adolescence. ( $7^{\text {th }}$ Edn) Boston: McGraw-Hill Companies,Inc. (check date?)

Thomas, H. Jamison, W., \& Hummel, D. (1973). Observation is insufficient for discovering that the surface of still water is invariantly horizontal, Science 181, 173-174

Tinajero, C., \& Paramo, M. (1997). Field dependence-independence and academic achievement: a reexamination of their relationship. British Journal of Educational Psychology, 67(2), 199-212.

Tsaparlis, G. (2005). Non-algorithmic quantitative problem solving in university physical chemistry: a correlation study of the role of selective cognitive factors, Research in Science and Technological Education, 23(2), 125-148.

Witkin, H. (1949). The nature and importance of individual differences in perception, Journal of Personality, 18, 145-170.

Witkin, H.A. Goodenough, D.R., \& Karp, S.A. (1967). Stability of cognitive style from childhood to young adulthood, Journal of Personality and Social Psychology, 7(3), 291-300.

Witkin, H. A., Oltman, P., Raskin, E., \& Karp, S. (1971). Group embedded figures test manual, Palo Alto, USA: CP. Press.

Witkin, H., A., Dyk, R. B., Paterson, H. F., Goodehough, D. R., \& Karp, S. A. (1974). Psychological Differentiation - Studies of Development, New York: Wiley.

Witkin, H. Moore, C. Goodenough, D., \& Cox, P. (1977). Field-dependent and field-independent cognitive styles and their educational implications. Review of Educational Research, 47, 1-64.

Witkin, H. A. \& Goodenough, D. R. (1981). Cognitive styles - essence and origins: Field dependence and field independence (New York, International Universities). 